Kapitel 7

\title{
Vakkelsespradikanten Kaptajn Jespersen mellem kald og videnskab
}

af Hans Bonde

"- Så er kaptajnen trådt af for lytterne - endnu i sit livs topform. Den store offentlighed har mistet en skikkelse, hvis betydning ikke kan måles i dag. Măske om 10 år. Eller snarere 25. Det tilkommerikke os, der ved afskeden gribes af folelser, tanker og minder, at felde en blivende dom. Det skal der generationer til. (l) $^{1}$

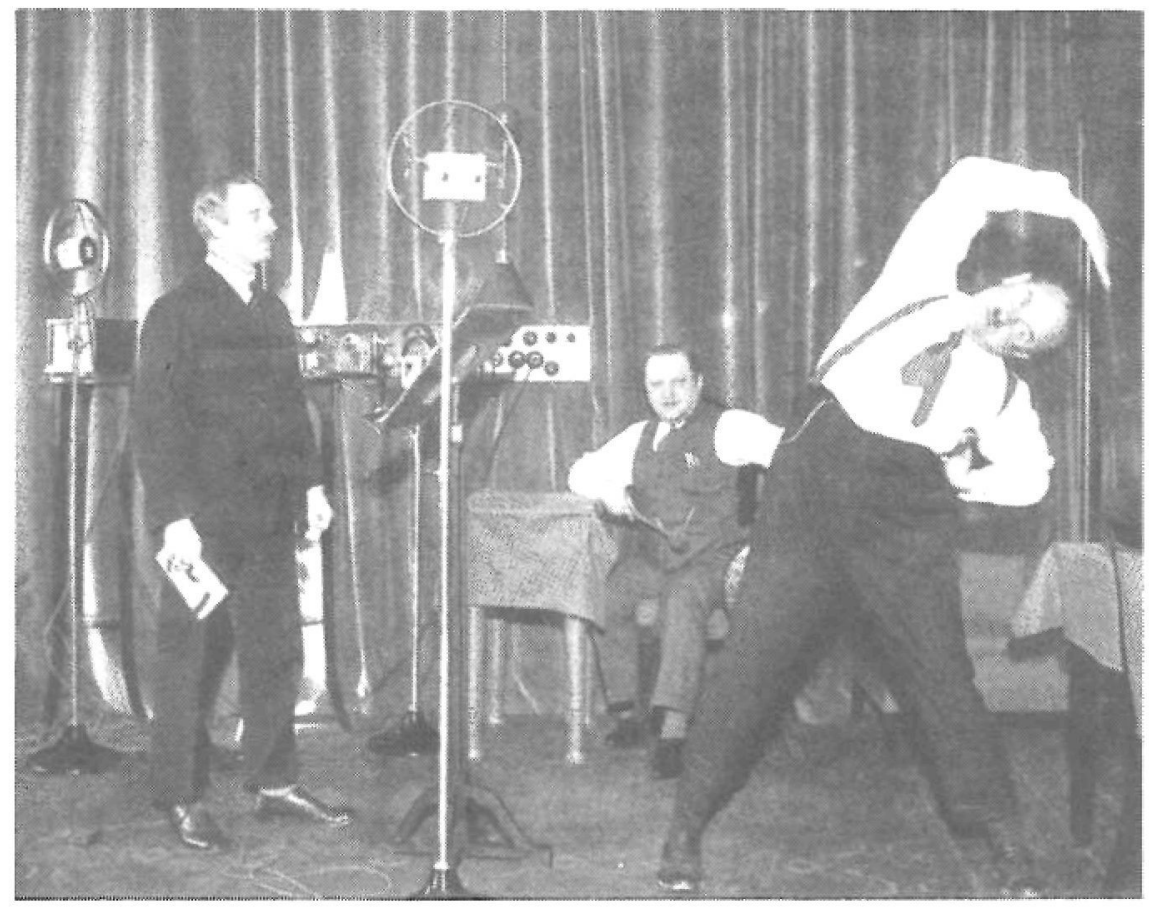


Det er i år 26 år siden, at én af dansk idrætskulturs store mænd døde. Er man over 45 år gammel, vil man huske »Kaptajnen «, hvad enten erindringen får én til at trække på smilebåndet, blive aggressiv eller vemodigt at tænke tilbage. Én ting er sikkert, Kaptajn Jespersen vækker følelser, uanset hvad man mener om ham. For en stor del af ungdommen, som ikke har nogen direkte erindring om »Kaptajnen«, er han et begreb, som associerer noget i retning af en militærisk stram kommandogymnastik og kolde afvaskninger. I dag synes Kaptajn Jespersen at have fået en renæssance. Nu og da dukker der artikler om ham op i dagspressen, og hans stemme gjalder igen ud af radioens højttalere som et ekko fra fortiden. Hvad gav Kaptajn Jespersen en så stor gennemslagskraft, at han blev en myte $i$ sin egen tid ? Hvorfra kom hans store khårisma? Det er klart, at en vigtig del af dette spørgsmål skyldes hans forbindelse med radioen, »dette lille vidunderapparat«, som udstråler en »alvorlig formaning $\ll .{ }^{2}$ ) Kaptajn Jespersens 25 år som leder af radio-morgengymnastikken fra 1927-1952 gav ham mulighed for at udbrede sit hygiejniske budskab til store dele af nationen, men forbindelsen til datidens nyeste massemedium - som i sin barndom må have affødt en del respekt og andagt - kan ikke i sig selv forklare hans succes. Nutidens morgengymnastik forekommer da også at være en stille skovsø i forhold til Kaptajn Jespersens orkaniske frembrusen.

\section{RØDDER}

Jesper Peder Jespersen blev fodt den 18.7.1883 i landsbyen Lumby på Fyn. Om sin opvækst fortalte han:

»Min slagt var selvejerbonder $i$ ordets bogstaveligste forstand: der skyldtes ikke en ore på gården, min far ejede den helt. Der var 83 tonder land god, veldyrket jord, 8 tonder hartkorn. Sådan var den materielle baggrund for min barndoms solide hjem.

Gärden var resultatet af slagtens flid, nojsomhed og retskaffenhed. ...

Trods den solide okonomiske basis, mit barndomshjem hvilede på, måtte vi søskende tidligt op og rogte dyrene, og når skolen var forbi, var der et ganske bestemt arbejdsprogram for os. Sadan var vore forceldres indstilling. De larte os at bestille noget, at vare nojsomme og at vare taknemmelige. Sandhed, renhed og skonhed pragede al deres fard, og jeg er overbevist om, at det er det, der har gjort mig til et lykkeligt menneske. " ${ }^{3}>$

I sine erindringer udpegede Kaptajn Jespersen de »tre grundpiller« i sin barndom som: »Mit hjem, præstegården og skolen «, ${ }^{4}$ ) og jeg vil tilføje forsamlingshuset, hvor Jesper Peder lærte gymnastik af en korporal, »som ville lære os den lystbetonede selvdisciplin, den som jeg siden målbevidst har søgt at fremelske i mine tusinder og atter tusinder af elever ude over landet «. Jesper Peder "ville selv gerne have varet på Odense Latinskole, men da jeg stadig måtte udfylde min plads $i$ gårdens drift blev tiden forpasset". ${ }^{5}$ )

Om Kaptajn Jespersens akademiske aspirationer gik i retning af læge- eller lærergerningen melder hans erindringer intet om, men det ville ligge i logisk 
forlængelse af hans barndoms fascination af præstegardsmiljøet, at det var præstens sorte kjole fremfor lægens hvide kittel, som tiltrak ham. I øvrigt kan Kaptajn Jespersens bristede drømme om en akademisk karriere ses i hans definition af begrebet ånd, som absolut ikke var lig med intelligens. På mange måder hyldede Kaptajn Jespersen den absolutte handle- og åndskraft fremfor blot og bar viden, spekulation og intelligens. "Gør det, og gør det nu! " var et af hans manende mottoer. ${ }^{6}$ )

Kaptajn Jespersen gik ikke desto mindre den boglige vej: "... Det blev $i$ stedet for Odense Seminarium, hvorfra jeg tog skolelerereksamen i 1904, da jeg var 21 årgammel. Så gik turen til Statens leererhojskole i Kobenhavn, hvor jeg gennemgik år skur sus med gymnastik, anatomi, idret og peedagogik som hovedfag. ( ${ }^{7}$ ) Kort sagt Jesper Peder Jespersen blev lærer, og dette pædagogiske element $i$ hans dannelse har givetvis haft stor betydning for hans ideer om folkeoplysning. I sine talrige foredrag optrådte Kaptajn Jespersen ofte som en klartseende og nærmest pedantisk skolelærer, for hvem man intet kunne skjule, og med en selvfølgelig ret til at hive mennesker frem fra publikum for så offentligt at revse dem for deres fysiske efterladenhed:

"Nu tager vi én lige ud af flokken og ser så, hvordan det heenger sammen. $J a$, man kan le over det, ja, man kan grede over det. Nu ler de af det, fordi han ser morsom ud,... men når De skal betale Deres skat, som er en del afdet der skal betales for at afstive det vaklende helbred, sả ler De ikke mine damer og herrer. Nu skal De se realiteten, vi måler altså denne herre. Det skulle vare således for at vare i form, da skulle hans brystmàl forholde sig til midjemålet som 11-10. Nu tager vi hans brystmål, han er såmend et meget almindeligt menneske også rent kropsligt set, han måler om sit bryst 102 om..., det er meget normalt. Men nu leggger vi målebåndet ned om hans mave og dér måler manden $130 \mathrm{~cm}$, det vil altså sige, at efter idealet skulle han højst måle $90 \mathrm{~cm}$, han måler altså, selv om han tilsyneladende er en pen og velskabt mand, så måler han fyrretyve cm for meget om sin mave. «)

11907 blev Jesper Peder Jespersen indkaldt til hæren, "og det blev til, at jeg gennemgik fodfolkets sekondlojtnantskole, og kom til at slå ind på en helt anden vej endjeg oprindelig havde taenkt mig «. ${ }^{9}$ ) Som bekendt opnåede Jesper Peder Jespersen at blive kaptajn. Lyden af hans kommanderende tone med de rullende r'er, som gjaldede gennem radioen befæstede hans folkelige navn som »Kaptajn Jespersen《 og ikke $f$.eks. »Lærer Jespersen« til trods for at han fortsatte sin lærergerning parallelt med sin officerskarriere. Kaptajn Jespersens militære baggrund viste sig ikke blot ved hans barske og bydende måde at kommunikere (læs: Kommandere) på, men også i selve hans livsfilosofi. I alle Kaptajn Jespersens skrifter spillede begrebet $» k a m p \ll$ en stor rolle. Tilværelsen sås som en stadig »kamp« mod mørkets magter og lysets fjender i og udenfor éns eget sind. Der fornemmes en klar socialdarwinistisk inspiration hos Kaptajn Jespersen, ${ }^{10}$ ) og ind imellem overførte han direkte krigsskuepladsens erfaringer til den daglige $»$ kamp for tilværelsen «: 


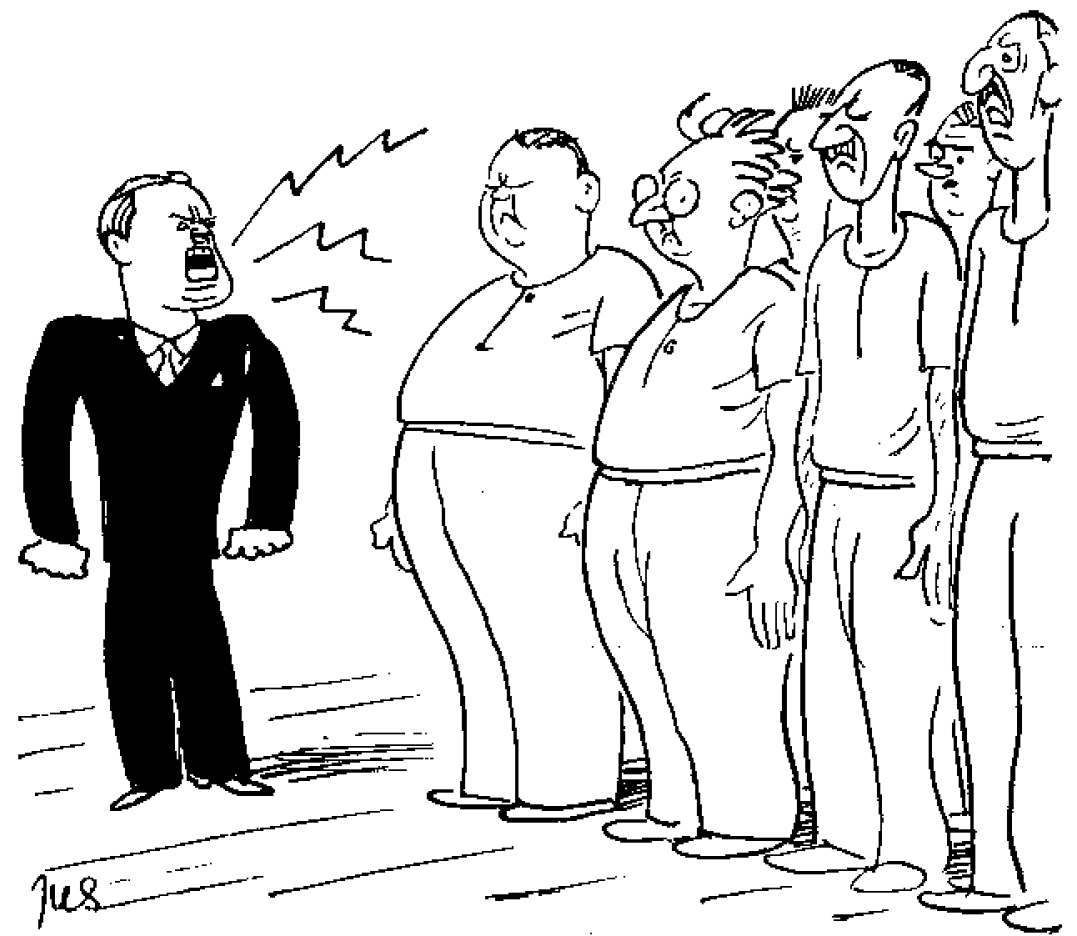

Kaptajn Jespersen skal på Hindsgavl have et »afslapningskursus« for »hjemmenes og kontorernes buldrebasser«, de rastlose og nervose mand.

»En soldat skal vare hurtig $i$ opfattelsen, tro i bevarelsen og sikker i gengivelsen, hvasøjet, rankrygget og med en vilje og handlekraft skarp som en ragekniv. Eksercerpladsen er den esse, hvor disse egenskaber skal øves og proges til storste fuldkommenhed, således, at soldatens hele personlighed er proget heraf: Kun da vil han bestå virkelighedens svare prove. Som han er på eksercerpladsen, säledes er han på slagmarken. Den afgorende betingelse for at erhverve en sådan helstobt personlighed er daglig selvtugt og opoven $i$ ubrydelig lydighed mod krigens nådeløse lov....

Men overfor mu alt dette fra slagmarken til den tilsyneladende fredelige hverdag arbejdsplads, så vil De se, at det intet forandrer ved kendsgerningerne. Hver dag er jo en kamp under en eller anden form, hvert menneskeliv kender til konflikt og strabadser, til kravende, provende oplevelser, til øjeblikke, hvor virkelighedens svare prove skal bestàs.

Er De da rustet og tranet til at bestå denne prove? Er De en vardig reprasentantfor det land, hvis høje legemskultur alverden bøjer sig for? " ")

I sine erindringer drog Kaptajn Jespersen en parallel mellem hjemmets og præstegårdens betydning for den danske befolkning: 
"Vel har hjemmet den storste betydning for et barns indstilling, men når man som jeg er opvokset $i$ et landsbysamfund, ved man, hvor stor en rolle den kultur, der er udgået fra de danske prostegårde, har spillet for vort land. Mit tanke- og folelsesliv og min fantasi har i hoj grad suget naring i Lumby prostegård, hvorjeg mødte den adle og uegennyttige pastor Urban Hansen, der var en søn af rådmand Urban Hansen $i$ Odense, og stedets åndelige kulturberer sådan som en prest bor vare det. Der ligefrem voksede gudsfrygt om ham. Hvis et sogn er gudløst, har prosten utvivlsomt sit medansvar herfor... Det var ikke alene det, han sagde, der betog os, men måden hvorpå han sagde og gjorde det altsammen. Når han messede, vakte han ligesom noget helligt $i$ vore sind. Han virkede ved sin personligheds kraft, og der var over hans ansigt et både mildt og bedrovet skcer, der kaldte på det bedste $i$ os. ${ }^{12}>$

Præstefamilien fik en endog større betydning for Jesper Peder Jespersen, da han efter et langt barndomsvenskab i 1907 giftede sig med Lumbypræstens adoptivdatter Anna. ${ }^{13}$ )

I sine erindringer roste Kaptajn Jespersen ofte nøglepersonerne i sit liv med de egenskaber, han selv stræbte mod. Beskrivelsen af pastor Lumby er i bøj grad en beskrivelse af Kaptajn Jespersens idealbillede af sig selv: Om Kaptajn Jespersen spredte tryghed og glæde kan vel diskuteres, men at han »virkede ved sin personligheds kraft « kan ikke betvivles. Kaptajn Jespersens dybt religiøse prægning fra barndomshjemmet ${ }^{14}$ ) og præstegården gav ham en fortolkningsramme til tre dramatiske hændelser i hans liv, som vi nu skal se nærmere på.

\section{KALDET}

Kaptajn Jespersens erindringer præges i forbavsende grad af hans oplevelser på hesteryg. Hvad var det som tilsyneladende gjorde hesten til det skæbnesvangre element i Kaptajn Jespersens liv?

»Jeg var ti år gammel og var blevet sendt udpå en afvore marker for at ride en hest hjem. Tempoet var som sadvanlig mere end friskt. Det var det sus, farten gav $i$ mine orer, muskelspillet $i$ hesten, selve flugten, der kaldte pà den bundne vildskab $i$ både dreng og hest. Jeg var $i$ den grad besat af øjeblikkets spanding, at jeg glemte at regne med centrifugalkraften, da hesten forandrede bevagelsesretning for $i$ en skarp vinkel at dreje ud af ledhullet til landevejen. Folgen var, at jeg fortsatte ligefrem på hovedet $i$ en stendysse, og lå der med hjernerystelse og siden var bevidstløs en dags tid. Men i 1893, da dette fandt sted, var der ikke noget, der hed lage og 3 ugers sengeleje for "sàdan en bagatel «. Nej, en rask dreng var med i gårdens rytme dagen efter, ikke aftvang, men af gloede over at vore deltager $i$ det afvekslende, friske herdagsliv, der leves på en sädan gärd. " ${ }^{15}>$

Jesper Peders første uheld på hesteryg gjorde på fatal vis hele hans liv til en personlig kamp mod sygdom og depression og for sundhed og livsduelighed. 
Indtil Kaptajn Jespersen blev 52 år gammel i 1935 var hans hverdag præget af »en svimmelhed, der formørkede mit sind og handicappede mig i leg og arbejde«. ${ }^{16}$ ) Det tjener Kaptajn Jespersen til ære, at han - sundhedsapostlen over alle - i sine erindringer erkendte, at det ikke lykkedes for ham selv at befri sig for sin barndoms smerte, men måtte ty til den alternative medicin. Før konfrontationen med sin frelser, kiropraktor Simonsen, var Kaptajn Jespersen fyldt med hån og skepsis, men efter nogle få behandlinger kunne han ryste »mit livsåg af mig«, han var nu udfriet af »svimmelhedens klamme tågetilværelse $\ll .{ }^{17}$ )

Inden denne helbredelse havde Kaptajn Jespersen haft endnu to rideuheld, som dramatisk ændrede hans liv. Efter 1907 blev Kaptajn Jespersen udvalgt som ordonnansofficer for regimentchefschef P.M. Møller fra 5.regiment, der lå i Nyborg. I denne forbindelse blev Kaptajnen beordret til at gennemgå en grundig skole i ridning ved 2. dragonregiment i Odense. Da han en dag ville stifte nærmere bekendtskab med en ny, særdeles kåd og ilter hest ved at lade den gå på volten i ridehuset, løb situationen løbsk:

»Pludselig, mens jeg legede lidt med min nye ven på volten, skred nogle af snemasserne ned ad ridehusets tag, og enhver kan forestille sig det adle dyrs forskrakkelse og dets noget ubeherskede optraden. Afforen endte med, at jeg rog af men uheldet ville, at min ene spore blev viklet ind i ridedckkenet, hvorvedjeg kom $i$ den for en rytter mest prekcere situation: hesten ogjeg var alene $i$ ridehuset, ogjeg hang $i$ den ene spore $i$ sadlens underlag med skuldre og hoved ned pà jorden, men heldigvis med begge honder $i$ et fast greb i tojlen. Sneskredene på taget gentog sig imidlertid, og hver gang sprang hesten sidelans, mens jeg hang der hjolpelos og med udsigt til at blive slobt sonder og sammen. Portvagten, der patruljerede udenfor ridehusene kom pludselig tilstede. Han havde anet uråd, da han horte det uscedvanlige spektakel inde fra ridehuset. Han afvargede ulykken -jeg kom fri. ${ }^{18}>$

Som om dette ikke var nok, red Kaptajn Jespersen ind i sit tredje og denne gang mest skæbnesvangre uheld til hest, da han efter 1912 var blevet stationeret i Århus som tjenstgørende og efterhånden korpsfører for Århus Amts Rekylkorps (Korps Westenholz):

"Jeg havde en pragtfuld, stcerk hest og folte mig sikker, men midtpå skråningen var der et balte af sne og is med store luftrum $i$, og her gik hestens forhove igennem. Derved tabte den balancen, drejede skrät, sà den gled sidelons, og $i$ min anstrengelse for at rette hesten op, gled min venstre fod igennem bøjlen. Hesten fortsatte glideflugten, akkurat som en kalk til kloftens bund med mig hoengende $i$ bøjlen, og derefter fulgte den de andre heste $i$ kraftige spring op ad den modsatte skrcent.

Og nu skete det mirakel, der udfriede mig af den frygteligste situation, en rytter kan komme ud $i$ : en skrckslagen hest $i$ vild galop med sin rytter hangende $i$ bøjlen. Da hesten befandt sig midt på bakkeskråningen, gik halen, hvori sporen var fastgjort, af stovlen, og min fod gled ud. Et råb til himlen: tak! Resten af mit liv: takl ${ }^{19}$ ) 
At Kaptajn Jespersen angiveligt rakte hænderne mod himlen i taknemmelighed over sin »frelse«, er langtfra nogen usædvanlig reaktion. Mennesker som kommer ud for dødsoplevelser, men slipper fra dem i live, føler ofte et gennembrud til en helt anden, ofte religiøst præget, virkelighedsopfattelse. Psykiateren Stanislav Grof har i samarbejde med Joan Halifax udforsket en lang række såkaldte nærdødsoplevelser. Disse to forskere konkluderer, at mennesker som konfronteres med deres egen død ofte oplever at møde et stort lyshav, hvor de mødes af et væsen, som de - typisk for mennesker fra den vestlige kulturkreds - af og til identificerer som Jesus. ${ }^{20}$ )

Kaptajn Jespersen fortceller ikke, hvad han oplevede $i$ de dramatiske sekunder, hvor han hang i stigbøjlen, måske afblufardighed, men han udtrykte, at "mine tre rideuheld har gjort et så varigt indtryk på mig, fordi der hver gang har varet noget mirakulost ved min redning. ${ }^{21}>$

Det kan i denne sammenhæng være interessant at nævne, at en anden af det tyvende århundredes store gymnastikpædagoger, Kaptajn Jespersens læremester, LP. Muller i sin barndom også flere gange var nær ved at dø. Muller berettede:

MMin Fader havde flere Legemssvagheder, og selv vejede jeg ved Fødslen kun 3 pund og kunde ligge $i$ en almindelig Cigarkasse. To Aar gammel var jeg Døden nor af Blodgang, $i$ Opvaksten havde jeg alle Børnesygdomme, og $i$ min forste Skoletid var jeg stedse syg et Par Gange om Aaret (Forkolelsesfebre, Diarré o.s.v.) - Min muverende Styrke og Sundhed har jeg altsaa hverken faaet $i$ Arv eller grundlagt $i$ de forste Barneaar. Det er Egenskaber erhvervede ved Legemsøvelser, der Aar for Aar foretoges efter en formuftigere Plan. «J?l

Måske kan den glød, den khårisma, den ubændige viljekraft og tilsyneladende urokkelige tro på sin mission, som flere af idrætsbevægelsens pionerer udstrålede, kun forstås i sammenhæng med dybtgående biografiske oplevelser af død og sygdom. For LP. Muller og Kaptajn Jespersen var sundhedsspørgsmålet ikke i første omgang et intellektuelt, medicinsk anliggende, men en dybtfølt personlig kamp, en kamp, hvis helbredende ritualer de på næsten messiansk vis ønskede at indvie den øvrige befolkning i. ${ }^{23}$ )

Kaptajn Jespersens prøvelser var dog ikke forbi med hans tre uheld til hest. 11930, mange år efter sit tredje og sidste uheld, måtte han underkaste sig en operation, der i nogen grad var en følge af hans rideuheld. Sytten dage efter indgrebet indtraf der svære komplikationer med årebetændelse, gulsot og blodprop. På et spørgsmål om han kunne deltage i efterårsmanøvrene, svarede reservelægen: »Det ben bliver aldrig til soldaterben mere. « Det svar efterlod Kaptajnen »i en sindsstemning, der ikke begunstigede helbredelsen «. ${ }^{24}$ ) Overlægen, som havde foretaget indgrebet, besøgte Kaptajnen hver aften for at opmuntre ham. En aften hvor Kaptajn Jespersens humør var særlig langt nede, sagde overlægen nogle få ord, som den sygdomsmærkede Kaptajn Jespersen greb med kyshånd, $\mathrm{j}$ a de forandrede angiveligt hans liv. Overlægen sagde følgende ord: "Hvad ved vi lager, når det kommer til stykket, om de krcefter, der rorer sig $i$ det menneskelige legeme« ${ }^{25}$ ) Overlægens ord vakte 


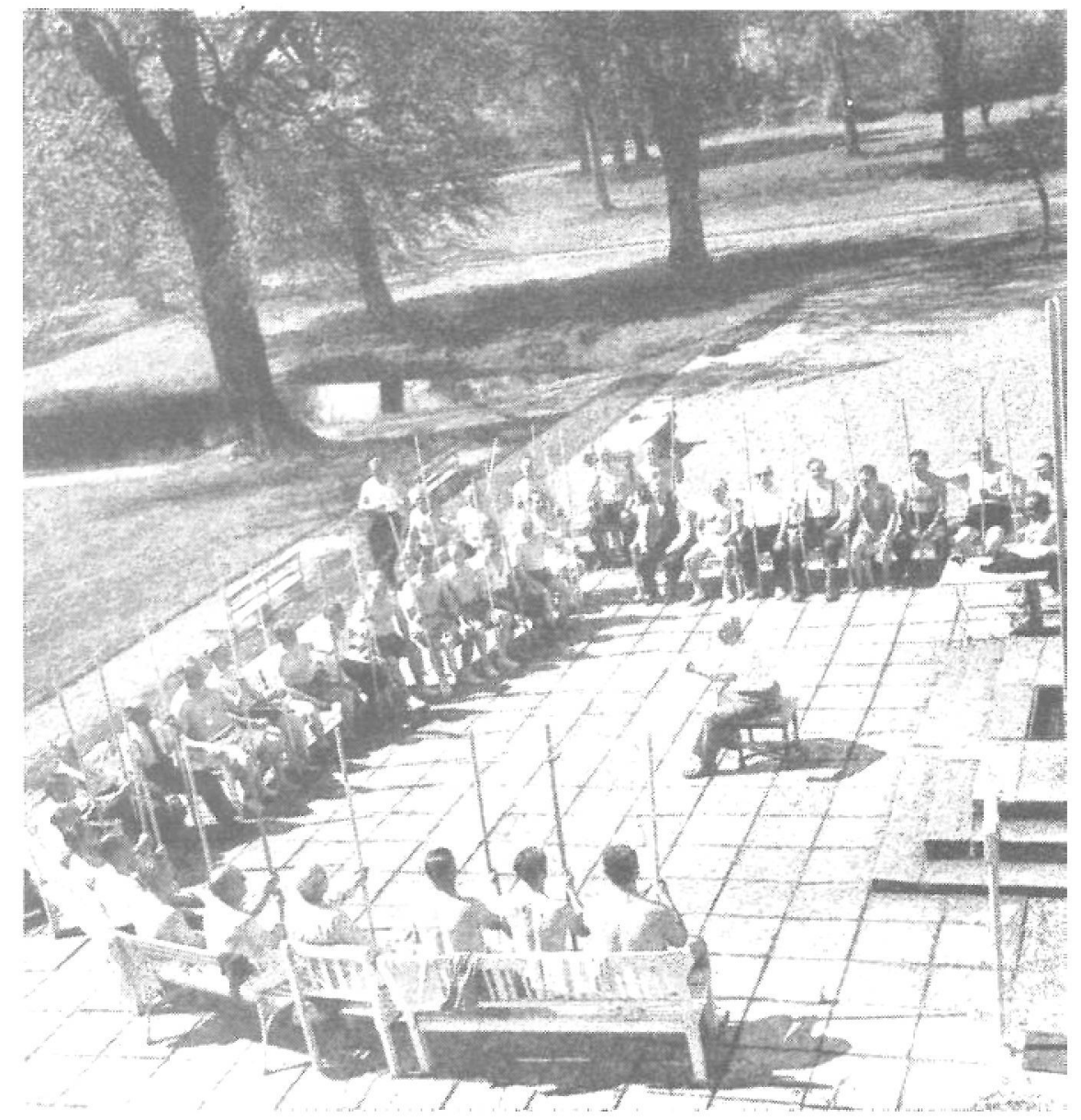

angiveligt stærke følelser i Kaptajn Jespersen, for hans kommentar til dem var: "Gud velsigne Dem, overloge Helsted, for disse vise ord", og han fortsatte med at beskrive, hvordan ordene havde virket som et kald på ham, et kald om at tjene Gud:

"Den selvtugt, trcening og hoerdning, jeg tog fat på fra den dag, jeg forlod hospitalet, og som jeg blev ved med indtil dagen i dag, var resultatet afen beslutning, jeg tog den aften overlage Helsted giorde mig opmcerksom pà de skjulte krofter, der rører sig i hvert eneste menneske.

Og således blev den forbandelse, sygdommen scenkede over mig, forvandlet til den velsignelse, der består $i$ at tro på livet og uden at vakle tage kampen op mod livets fjender.

Selv klarede jeg pynten, og mange tusinde lyttere har siden fortalt mig $i$ breve og personligt om lignende kampe, der forte til sejr, snart fysisk og-meget, meget ofte - sjceleligt. 
Nårjeg igen kaster mig ud i kampen for at erhverve idrcetsmorket, er deten akiivitetsappel til mine gamle lyttere. Glem ikke, hvad vi i radioen măske indtil trivialitet for de passive fastslog: kampen for sundheden vil aldrig ophøre. Man ejer også på det omràde kun det, man selv har gjort sigfortjent til. Men den, der kcemper redeligt, vil pä den ene eller anden mäde blive belonnet. ${ }^{26}$ )

Benet blev aldrig helt som før, men tjente dog som soldaterben tiden ud. Kaptajn Jespersens vækkelse lettede ham i den følelse af meningsløshed, afmagt og dyb pessimisme, som skyllede gennem ham efter operationen. Vækkelsen betød, at der var en mening med hans lidelser, som han nu forstod som prøvelser. Kaptajn Jespersens meget håndfaste måde at tolke sundhed og sy gdom på, viser sig meget klart $\mathrm{i}$ hans hyppige direkte koblinger fra religiøse oplevelser til hverdagens hygiejniske praksis. I det foregående større citat koblede han således direkte fra sin vækkelses-førn/? for at undgå livslang invaliditet til sin kamp for at erobre idrætsmærket, hvilket han anså for en aktivitetsappel til sine gamle lyttere.

Kaptajn Jespersen beholdt sine to ben at gå på, og også mentalt gik han på to ben. »Kaldet« og »videnskaben《 gik hånd $\mathrm{i}$ hånd inkarneret $\mathrm{i}$ overlæge Helsted. Repræsentanten for den fremstormende naturvidenskabeligt funderede lægekunst blev den autoritet, der i den afgørende stund viste Kaptajn Jespersen hen til »de skjulte kræfter, der rører sig i hvert eneste menneske«. Kaptajn Jespersens udvikling fra gymnastikpædagog til hygiejniker byggede på en ejendommelig, men kraftfuld sammensmeltning af forgangne århundreders stærke, men nu defensive kristne protestantisme og den fremstormende naturvidenskabelige medicin. Hy giejnikeren blev præst, og læge. ${ }^{27}$.)

\section{KALDSETIK}

11930 da Kaptajn Jespersen fik sit endelige kald til at arbejde i Guds tjeneste, var han allerede en etableret gymnastikpædagog med eget institut, årlige sundhedsstævner på Hindsgavl, for ikke at tale om hans radioarbejde. Kaldet betød, at Kaptajn Jespersen bombastisk kunne erklære, at han »ikke var gymnastiklarer ${ }^{28}$ ) Gymnastikken måtte blive "et livsprincip, ikke blot et fag $\left.{ }^{29}{ }^{29}\right)$ Når Kaptajn Jespersen beordrede sine lyttere op af sengen i den årle morgenstund søgte han ikke kun at vække dem fysisk, men også religiøst. Kaptajn Jespersen blev en vækkelsesprædikant med kroppen som medium. Det var derfor ikke mærkeligt, at han kunne erklære, at »kirken og idratten er vore hjoelpemidler « $\mathrm{i}$ bestræbelserne på at nå »højere fuldkommenhed ${ }^{30}{ }^{30}$ ) Kaptajn Jespersens trofaste fans betegnede ham da også af og til som »vækkeren « eller »samvittighedsvækkeren « ${ }^{31}$ ) og i dagspressen betegnedes han ofte med en blanding af ironi og alvor som »sundhedsapostel«.

I sine erindringer skrev Kaptajn Jespersen:

"For at udelukke enhver misforståelse vil jeg sige: jeg betragter ikke mig selv som en selvglad, halvstuderet rover på det teologiske område, ej heller som en skinhellig lagprodikant, men som en aldre kavaler, der har haft et uscedvan- 
ligt lykkeligt og begivenhedsrigt liv, og som er besjelet af en ubcendig trang til $i$ dyb taknemmelighed og efter fattig evne at hjcelpe sine medmennesker til at folge deres bestemmelse og soge hojere fuldkommenhed. $"{ }^{32}>$

Kaptajn Jespersens kald indebar, at han opfattede det som sin nærmest messianske pligt at hjælpe de syge og svage. Han fastslog også ofte på god kristelig maner, at i hans verdensbillede var der ingen forskel på høj og lav. Dog viser regnskaber og protokoller for hans »Hygiejniske Instituts « virksomhed, at hans virksomhed på dette felt stort set ikke nåede ud over de absolut velstilledes rækker. ${ }^{33}$ ) Ej heller radioen var vel i dens begyndelsesfase menigmands eje. I øvrigt var langt de fleste af Kaptajn Jespersens lyttere kvinder. $\left.{ }^{34}\right)$ Efter at have opregnet sine resultater på sundhedens område gennem 25 års virke ved radioen, konkluderede Kaptajn Jespersen i sin afskedstale den 30. august 1952:

«eg er lykkelig over disse resultater, fordi det viser, at det har betydet hjolp til de hjolpelose, trost og opmuntring til de slagne, de bedrovede, sundhed til de halvt-raske, styrke til de svage og glade til de gladeslose. Disse resultater svarer noje til det, jeg altid satte mig som mål. ${ }^{35}$ )

Skønt Kaptajn Jespersen mente at kunne vække folks trang til at - med to af hans klassiske formuleringer - "udfolde deres uendelige udviklingsmuligheder" og "soge hojere fuldkommenhed", søgte han ikke at tage ansvaret ud af hånden på det enkelte individ. Det var den enkeltes eget ansvar at søge kontakt med »de skjulte kræfter «. Frelsen var en privatsag som viste sig i et personligt gudsforhold opnået gennem en »sand« og »ren《 livsførelse. Målet for hin enkelte var, sat kunne vere alene med naturen og Vorherre « ${ }^{36}$ ) Kaptajn Jespersens egne "prøvelser « var jo netop af individuel karakter, og han formulerede sit gudsforhold således:

"Den opfattelse, at et altseende veesen er vidne til vor fard, og den deraf folgende trang til at onske $i$ alle situationer at holde fast på den »sterke hånd over skyerne", har på en mirakules måde hjulpet mig $i$ alle svcere perioder og virket som en beskyttelse og velsignelse. ${ }^{37}$ )

Kaptajn Jespersens forhold til den mikrofon som forbandt ham og radioen med lytterne minder om den samvittighedsfulde præsts forhold til sin prædikestol.

"Derfor folte og opfattede jeg overhovedet ikke mig selv som gymnastiklarer-allermindst foran mikrofonen. Dér folte jeg derimod, at jeg var et bydigt tankens redskab, og jeg folte migfast overbevist om, at de tanker og folelser, der blev indgivet mig, var den strålende virkelighed, som er indenfor vor reekkevidde. ${ }^{38}{ }^{38}>$

\section{GYMNASTIK OG VAKKELSE}

Med til Kaptajn Jespersens kaldsetik hører en vis fatalisme. I et interview svarer han på spørgsmålet om han kunne være blevet noget andet end han blev? »Ligegyldigt hvad jeg var blevet, var jeg blevet hvad jeg er « ${ }^{7}>$ og ofte slår han til lyd for, »at vi folger vor bestemmelse og hele livet viser lydighed 
mod loven «. ${ }^{40}$ ) På trods af denne forestilling om »bestemmelse «, som leder tanken hen på Luthers kaldslære, fremmanes faren ved ikke at slå ind på $» l y$ sets, sandhedens og sundhe dens kongeve $j$ « igen og igen ${ }^{41}$ ) Faren var for Kaptajn Jespersen klar: Guds straf ville være uundgålig. ${ }^{42}$ ) Kaptajn Jespersen lagde ikke skjul på, at for ham havde livet været én lang »provelse« præget af voldsomme indre kampe. ${ }^{43}$ )

Kaptajn Jespersens religionsopfattelse må fortolkes i sammenhæng med hans opvækst $i$ et religiøst bondemiljø. For selvejerbonden, som forlængst havde forladt landsbyfællesskabets relativt sikre havn, var omstillingen til at producere for et marked blevet et spørgsmål om at tage sig selv gevaldigt $\mathrm{i}$ nakken, at udvikle en selvdisciplin, som muliggjorde en forbliven i en branche, hvor markedets svingninger eller egen mangel på arbejdsdisciplin kunne betyde en afgrundsdyb gældssætning eller i værste fald konkurs. Efter landboreformerne fejede pietistiske bevægelser hen over bondelandet i forste halvdel af 1800-tallet. Disse vakkelsesbevægelser er af litteraturvidenskabsmanden Martin Zerlang blevet fortolket som vigtige socialpsykologiske .. "produktionssteder « for udviklingen af den ny »kapitalistiske and «. ${ }^{44}$ )

Denne »kapitalistiske ånd «, som sociologen Max Weber kaldte den ${ }^{45}$ ), var præget af evnen til langsigtet kalkule, styring af drifterne og en form for "verdslig askese«. At opleve en pietistisk vakkelse indebar at opnå nåden gennem en skelsættende religios oplevelse, som opfattedes som et Guds kald til det enkelte menneske. Dette kald udmundede i voldsomme bodskampe, hvor den vakte kæmpede for at frigøre sig fra sit tidligere »syndfulde« levned, ofte karakteriseret ved druk, hor og dovenskab. For at opnå »salighed « i det hinsides, altså frelse og overgang fra jordisk til himmelsk liv krævedes der en streng opfyldelse af kaldspligterne, det vil sige at leve et liv præget af hårdt arbejde $i$ sit ansigts sved og en afståen fra sanselig nydelse. ${ }^{46}$ )

Hvor forestillingen om askese i katolicismen især var en livsvej for munke og eremitter, blev den protestantiske askese med Luther hevet ned på jorden, som et krav til menigmand om at gennemfore et asketisk hverdagsliv. ${ }^{47}$ ) At kunne fremvise et liv præget af flid, hårdt arbejde og verdslig askese blev det centrale tegn for de vakte pietistiske bønder. Det afgørende spørgsmål for den enkelte blev: »Er jeg blandt de udvalgte«, og gennem et arbejdsomt, stræbsomt og fromt liv søgte man - at fastslå sin position som medlem af Guds udvalgte skare. Det luthersk-asketiske kaldsarbejde blev den afgorende faktor i den vaktes forsog på at udrydde tvivlen om sin egen udvalgelse i sit sind. Efter den hårde bodskamp og omvendelse,blev den vakte ofte så » glad og frimodig «, at han onskede at delagtiggøre andre i sin glæde og derfor prædikede omvendelse for sine medmennesker, således lød i hvert fald $»$ s store trak de vaktes omvendelsesberetninger « ${ }^{48}$ ) Fra 1840 'erne begyndte der at opstå en splittelse i den religiøse bondestand mellem de som vedkendte sig den mere glædesbetonede, sanselige og jordisk orienterede "gårdmandsreligion", grundtvigianismen, og de som fastholdt det pietistiske grundsyn, inkarneret $\mathrm{i}$ »Indre Mission«. Denne skillelinje viste sig dog forst markant efter 1860. 
Martin Zerlang har sammenfattet den grundtvigianske livsanskuelse således:

"Modtagelsen af tilbuddet, af nàden, adskilte sig skarpt fra den pietistisk progede erhvervelse af nådestanden. Mens syndserkendelsen, angeren, bodsgangen, omvendelsen og helliggoreisen var det centrale i de vaktes kristenliv, indtog dåben hovedrollen $i$ grundtvigianernes kristenliv....

For den pietistisk vakte var salighedsvilkärene en streng opfyldelse afkaldspligterne, et alvorsfuldt-asketisk fromhedsliv, der udelukkende sigtede mod "det ene fornodne", en total bortvendelse fra synd. Grundtvigianerne forstod imidlertid bekrceftelsen af dåbspagtens »tror du« og »forsager du« som salighedsvilkårene. Gudsforholdet pregedes altså af en glad tillid til Guds nâde, som ikke indebar en afstandtagen fra "det menneskelige", fra detjordiske liv, og heller ikke konstant hensatte individet $i$ tvivl og angst m.h.t., om afgørelsens time ville resultere ifrelse eller fortabelse. ${ }^{49}$ )

Omkring århundredeskiftet kulminerede Indre Mission som en væsentlig faktor i det religiøse liv på landet. Med denne kulmination udbredtes den lære, at der var en del af menneskeheden, som var udvalgt, skarpt adskilt fra en anden del som var fortabt. Med denne adskillelse fulgte en fanastisk intolerance overfor de som ikke kunne blive salige. 11890'erne kulminerede den indremissionske ide om synds frihed og fuldkommelighed blandt de udvalgte også ${ }^{50}$ )

Men hvad har alt dette med Kaptajn Jespersen at gøre? Det er min hypotese, at Kaptajn Jespersens hygiejneopfattelse foruden en helt fundamental Luthersk-Paulinsk inspiration rummer elementer af både pietistisk og grundtvigiansk karakter. Hans konstante prisning af askesen går hånd $i$ hånd med en livsglæde og en optimisme i det jordiske liv her og nu. Samtidig rummer hans hygiejne en meget bastant ide om kropslig selvtugt, som ikke i den form fandtes i de to store landlige trosretninger. ${ }^{51}$ ) Kaptajn Jespersens tidlige religiøse påvirkning stammede fra hans mor, men hvilken karakter hendes indflydelse havde, ved jeg ikke. Kaptajn Jespersen fortæller blot, at det skyldes hans mor, "når jeg kender bønnens kraft i den grad, som tilfældet er « ${ }^{52}$ ) Kaptajn Jespersens anden store religiøse erfaringsverden blev prestegården i Lumby. Om præsten berettes det, at han var påvirket af én af de centrale grundtvigianske pionerer Vilhelm Birkedal, som imidlertid i det mindste frem til 1860 var stærkt pietistisk præget. ${ }^{53}$ ) Endvidere fortælles det om landsbypræsten Urban Hansen, at han var »mild og folkekær«. At megen af Kaptajn Jespersens tænkning endog helt ned i ordvalget var præget af en fundamental Luthersk-Paulinsk tankegang kan ikke undre al den stund Luthers Katekismus var børnelærdom i det danske skolesy stem i Kaptajn Jespersens barndom. ${ }^{54}$ )

Kaptajn Jespersens livsfilosofi indeholdt tilsyneladende ikke forestillingen $\mathrm{om}$, at nogle mennesker på forhånd er udelukket fra at kunne indgå i det himmelske rige. Alle mennesker har tilsyneladende skjulte guddommelige krefter i sig, kræfter som blot skal vækkes. Dette betyder dog ikke, at man i Kap- 
tajn Jespersens verdensbillede skulle forholde sig forsonligt og mildt til alle mennesker. Tværtimod blev det næsten en dobbelt synd ikke blot at træde væk fra Guds »kongevej«, men oven i købet selv at kunne gøre for det. Den mere eller mindre bevidste pietistiske forestilling om at udvise tegn på, at man var bærer af Guds ånd forefandtes også - omend i en ny udformning hos Kaptajn Jespersen, som tordnede mod de dovne, ugidelige og nydelsessyge mennesker, som forspildte deres chancer for at modtage Guds »åbenbaring «, »besjæling « og »beskyttelse «. Om der var tale om en salig tilstand $\mathrm{i}$ himlen efter døden lod Kaptajn Jespersen stå åbent, men i sin alderdom kunne man i det mindste samle sig »visdom i Gud, som kan mildne den kolde vind, der til sin tid vil blæse dig i møde fra den åbne grav. $\aleph^{55}$ ) Som hos pietisterne anbefalede også Kaptajn Jespersen askese som den vej, der åbnede menneskesindets låg til de skjulte kræfter. Det vil sige Kaptajn Jespersens nøglebegreb var ikke askese, men selvtugt, som implicerer noget kropsligt, det er legemet, som skal tugtes af ånden:

"Hvor tonker vi $i$ almindelighed ringe om det at vere menneske- iforhold til at vi fra naturens hånd er udrustet med udviklingsmuligheder, og at livets devise er: Kampe du må $i$ den lobende tid, livet hernede er strid.

Denne livsbetingende kamp består forst og fremmest $i$ kampen mellem de modsatninger, der består i legemets tilbojelighed til sanselig nydelse, og sjalens, ändens krav om skønhed og renhed. "Hvad nytter det, at sanserne jubler, når sjelen grceder. «Anden må betale for legemets gald. Livets kamp består da forst og fremmest i kampen med sig selv. - Selvtugt. Dette er kernen i vor kultur og dannelse. ${ }^{56 \wedge}$

Når Kaptajn Jespersen priste den »jernhånd «, der kunne styre den syndige $\mathrm{krop}^{57}$ ) ses det, hvor tæt han er dels på pietismens kaldsetik og mere generelt på hele den luthersk-kristne dualistiske opfattelse af menneskets splittelse i en ophøjet ånd og en lav, frivol og dyrisk kødelighed. Dette til trods for, at han som gymnastikpædagog og hygiejniker igen og igen betonede »legemskulturens rolle som en fuldgyldig parallel til åndskulturen«. At legemet trods alt var underordnet ånden afsløres dog $\mathrm{i}$ andre citater, som f.eks. her:

"Vi er jo ikke kod og blod alene, men ånd og ansvar s forpligtet liv; ånden må derfor vakkes og nares, så det ikke bliver til knogler og boblende muskler altsammen. Det er dog til syvende og sidst åndens højnelse og afklaring, det kommer an på. Legemlig sundhed og legemlig skonhed skal tjene højere formål, det $m a ̊$ vi altid $i$ vor idrcetsbegejstring holde os for oje. " ${ }^{58}>$

\section{KROPPENS RELIGIOSE TALE}

For Kaptajn Jespersen var kroppen potentielt et »Guds tempel « ${ }^{59}$ ), som kunne og burde rumme Guds ånd. Hvis de »skjulte kræfter« kom til udfoldelse, ville det vise sig i legemet. Og her er vi inde på det nye i forhold til den pietistiske søgen efter tegn på Guds virkekraft i det enkelte menneske. For Kaptajn Jespersen viste de centrale tegn på at være på vej mod »højere fuldkom- 
menhed « sig ikke blot ved den verdslige askese, men kunne direkte ses på menneskekroppen. Den krumme, fede, skæve og »deforme« krop var den syndige krop. Sygdom og grimhed blev i Kaptajn Jespersens verdensbillede et tegn på synd overfor den legemlige »vedligeholdelsespligt《 og overfor den pligt til selvtugt, som Gud krævede afhvert eneste menneske. Kroppen afslorede ubønhørligt om man var syndig eller »ren «: »Den store hær af deformerede og halvt udviklede mennesker, vi har i dette land.. . kan vi jo ligefrem $u d$ pege blandt folk ved deres skikkelse $\ll .{ }^{60}$ )

For Kaptajn Jespersen var kroppen sjælens spej1, »legemsfuldkommenhed « var »indicatorer for sjælens og karakterens udvikling og forædling «. 61) Det galdt derfor om, at:

»Du skal folge din bestemmelse, søge hojere fuldkommenhed, Du skal varne om det skonhedsmarke, om Du vil, det Guds billede, Skaberen har proget $i$ hvert af Dine 》led $i$ Dit legeme, der er åndens redskab, såvel som $i$ Din ånd. ${ }^{62}>$

Kaptajn Jespersen implicerer her på det nærmeste en form for kroppens religiøse semiotik, en »tegnteori«, hvorefter det skulle være muligt at dechifrere menneskets indre åndelige tilstand ud fra visse ydre, fysiske karakteristika. Kaptajn Jespersens tegnteori samt hans opfattelse af den fuldkomne krop som gudbilledelig, har givetvis hentet næring fra hans berøring med den Lingske gymnastik og Niels Bukhs Ollerupgymnastik, som jeg dog ikke kan komme nærmere ind på her. Forestillingen om kroppens »afsløring « af psykiske tilstande og egenskaber er i øvrigt med den moderne terapikultur igen kommet på mode, men nu unægteligt med andre tegnfortolkninger. ${ }^{63}$ )

Kaptajn Jespersens »tegnteori« rummer en forening af naturvidenskabeligt empirisk registrerbar data med indre, åndelige tilstande. Her fulgte han i den pietistiske traditions fodspor:

"I sammenheng med den udbredte tegnaflosning, hvor saligheden indiceredes af ydre, konstaterbare forhold, skulle troen vare objektivt konstaterbar og resultere $i$ aktivitet og asketisk handlen. $P$. G. Lindhardt kalder pietismen »kirkens »svar« på den rent empiriske videnskabs gennembrud og den begyndende sekularisering af samfundslivet og fastslår: »Kirken måtte empirisk vise sig virkelig effektiv - "nytte" er hovedordet i bade pietisme og oplysning - dels ved at skabe de andre, religiøse (psykologiske) erfaringer, dels ved at befordre den moralske vandel, det nye liv «. ${ }^{64}>$

Kaptajn Jespersen førte brugen af medicinske målemetoder så vidt, at han uafladeligt i bøger og foredrag slog til lyd for brugen af journaler med angivelse af vægt, højde, bryst- og midjemål samt dato for målingen. Kravene til det enkelte menneske var ganske klare. F.eks. skulle bry stmålet for en mand forholde sig til midjemålet som 11 til 10. Kaptajn Jespersen bemærkede sarkastisk i tilknytning hertil, at de fleste mænd over 40 - 50 år i modsætning til dette ideal lignede »en omvendt turnips «. ${ }^{65}$ ) Et andet krav var, at journalen måtte vise konstant fremgang. Kaptajn Jespersen udelukkede ikke på forhånd nogen fra det fællesskab, som skulle løfte mennesket op i en højere 

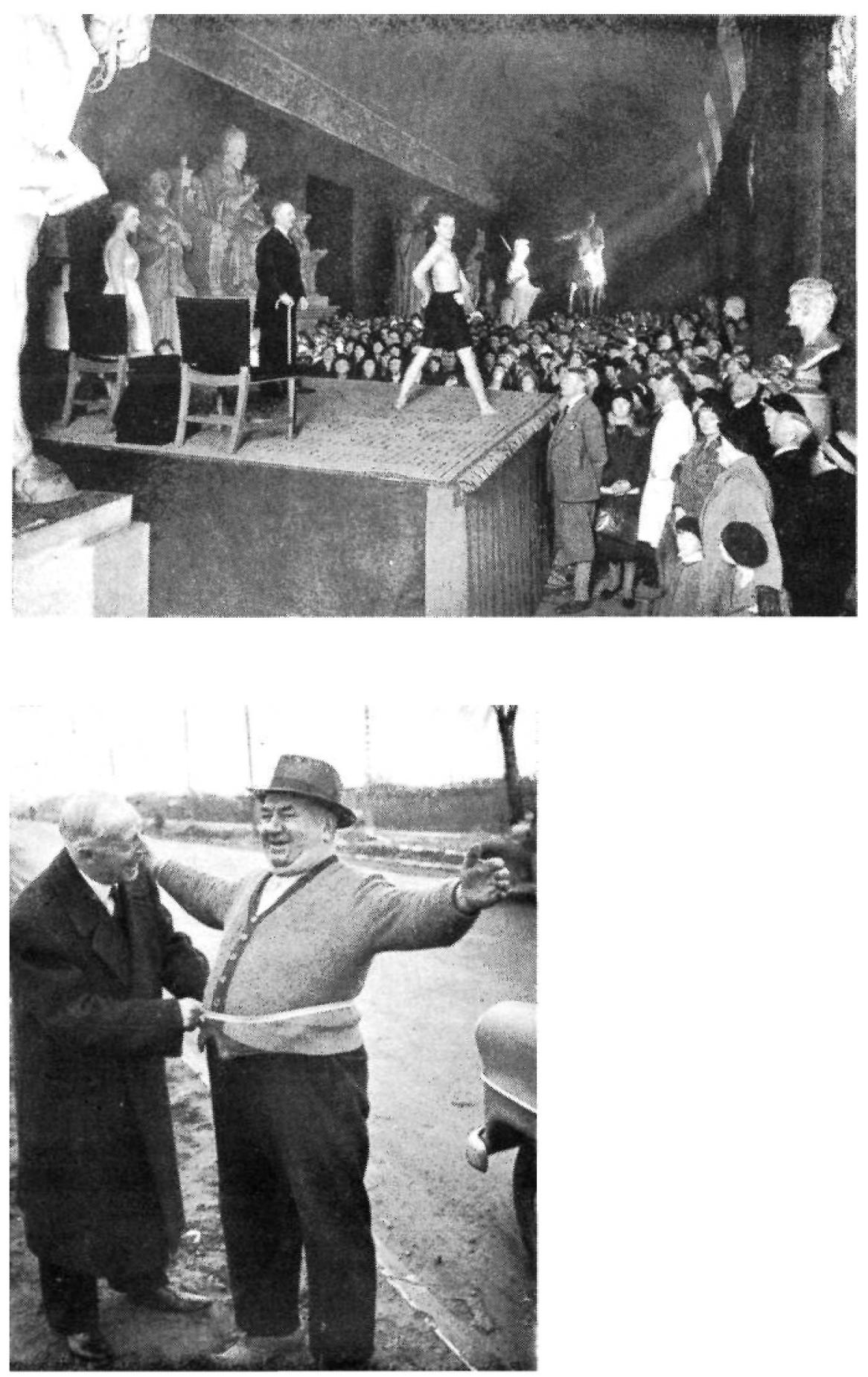
sfære kropsligt såvel som åndeligt: 》Selv den mest deformerede kan blive medlem af sammenslutningen, men med den forpligtelse, at han søger at blive $\mathrm{i}$ form $\ll,{ }^{66}$ ) Citatet indicerer, at det ikke i første omgang var kropslige tegn på, at man tilhørte de »forsømte, deformerede og defekte mennesker «, der trak ned ad i Kaptajn Jespersens bedømmelse, men den manglende vilje »jammer og hjælpeløshed « ${ }^{67}$ ), som hindrede det kropslige »genopby gningsarbejde«. »Gud ser på viljen«, og derfor kunne Kaptajn Jespersen også prise en driftig, energisk og suocesrig forretningsmand, som til trods for at have fået alvorlige handicap ved en bilulykke fortsatte sit »myreflittige« liv og »med sammenbidt energi og sejg udholdenhed « deltog i flere discipliner ved Kaptajn Jespersens sundhedsstævner på Hindsgavl. ${ }^{\infty}$ )

En driftig og flittig direktør, som levede rimeligt asketisk og gjorde noget for at »tugte sit legeme« var på mange måder Kaptajn Jespersens idealmand. Kaptajn Jespersen fordoblede pietismens krav om verdslig askese ved at kræve legemsøvelser som en form for legemstugt. Ikke kroppens lyst til bevægelse, men legemstugten blev kernepunktet i Kaptajnens idrætsopfattelse. Med en rationalistisk betonet fortolkning spurgte Kaptajn Jespersen om, hvad det nyttede at besejre verden, hvis man faldt om som 50-årig, fordi man undervejs helt havde forsømt sin pligt til at holde legemet vedlige.

Kaptajn Jespersens metaforsprog indeholder ikke kun en blomstrende religiøs sprogbrug, men i sammenhæng hermed også et økonomisk billedsprog. F.eks. sagde han: "Anden må betale for legemets gald «. ${ }^{69}$ ) I Kaptajn Jespersens erindringer indledes første afsnit med at slå fast, at: "Min slagt var selvejerbonder $i$ ordets bogstaveligste forstand: der skyldtes ikke en øre på gården«, og kapitlet afsluttes bl.a. med disse ord: "Enhver ulykke har virket på mig som en uafviselig appel til at udrette noget mere og bedre, i det ene ojeblik for at ràde bod, i det nastefor ikke at forlade livet som skyldner ${ }^{70}$ )

Kaptajn Jespersens økonomisk-religiøse metaforik gentager et tema som forefandtes hos de pietistiske bønder. Litteraturvidenskabsmanden Martin Zerlang noterer således:

"I Kingos og Brorsons salmer - der var udbredte blandt de vakte bønder møder man mange steder en sădan kalkulerende og rationelt-regnskabsførende holdning. Det fremgår udtrykkeligt af Brorsons »Kom Hierte! Tag dit Regnebret«. ${ }^{71}$ )

\section{Selvtugt}

At Kaptajn Jespersens snak om »selvtugt« ikke kun var retorik, ses af hans beskrivelse af i hvert fald sine tidlige øvelser, som på en moderne, blødsøden iagttager som undertegnede gør ondt alene ved læsningen:

»Stort Skridts Afstand mellem Fodderne. Kroppen bojes skraat fremad, nedad, til venstre, og idet Knoene holdes strakte, fattes om venstre Smalben med begge Honder.... Gennem stødvis Fremadbøjining af Kroppen gør man Forsøg paa at fore Panden ind til venstre Kne. Bøjningen forceres ved Trak af de bojede Arme." ${ }^{3}$ 
Kaptajn Jespersens antiidealmenneske var »sybaritten«, nydelsesmennesket, som forst og fremmest var kendetegnet ved sit umådeholdne indtag af føde og drikke. ${ }^{73}$ ) Det sikre tegn på denne last var den fede krop. Fedme var for Kaptajn Jespersen et af de værste tegn på et syndigt liv ${ }^{74}$ ) og han tilsluttede sig derfor den fremvoksende ernæringsvidenskab. Kaptajn Jespersen kunne næppe vide, at netop denne gren af videnskaben henimod det tyvende århundredes slutning skulle gå hen og blive én af de helt store hy giejniske bevægelser med egne »ernæringsprofeter« og »ernæringsguruer «, som det hedder i det folkelige dels vise, dels ironiske vid.

Det foregående skal ikke efterlade et billede af Kaptajn Jespersen som en totalt humorforladt, vrissen asket. Ofte slår han til lyd for glæden ved at bevæge sig, tage en kold dukkert eller tage den legitime daglige cigar. Alting med måde var devisen, og han afviste derfor sin mangeårige samarbejdspartner overlæge Ottosens adventistiske totalafholdenhed fra alkohol, kød og nikotin. Selv karakteriserede Kaptajn Jespersen sig i kontrast til sin kampfælle på sundhedsdyrkelsens område overlæge Ottosen, som »en naturens muntre son «, der »har respekt for og narer karlighed til livet- og Vor Herre «. ${ }^{75}$ ) I sine sene år gik han endvidere til dans. ${ }^{76}$ ) Af og til blev legemstugten forbundet med lyst, et fænomen der i øvrigt genfindes i sadomasochismen, som jeg dog ikke vil komme nærmere ind på her. ${ }^{77}$ ) I øvrigt blev mådeholdet $f$.eks. i relation til fødeindtagelse af og til set som en betingelse for den fulde nydelse af den rationerede genstand. ${ }^{78}$ )

\section{Djæevelen i kroppen}

Kaptajn Jespersens nøglebegreb, de »skjulte kræfter«, var ikke blot af guddommelig natur. I menneskesindet lå der også »skjulte kræfter«, som havde en helt anden farlig karakter og som truede med at overmande individet og drive det ud i synden. Disse kræfter var ondskabens kræfter. ${ }^{79}$ ) Tegnene på »det ondes« tilstedeværelse i kroppen var stivheder, svagheder og sygdomme, og kuren var gymnastik med hy giejnisk sigte:

"Selv den gymnastiske traning skaljeg ikke opholde mig ved, men blot give nogle forklaringer og retningslinjer. Alle bliver indstillet på, at ingen er ringere end han selv vil det. Her går det ud på at finde de stive, svage, syge steder i legemet og derefter udnytte de bevagelser, der bliver dikteret på en sådan måde, at de bekcmper, korrigerer og styrker, med andre ord driver det onde ud af kroppen. ${ }^{80}>$

Den hy giejniske gymnastiks opgave blev at "drive det onde ud af kroppen ", altså en form for hygiejnisk excorcisme. Alle Kaptajn Jespersens bøger er gennemsyret af en ransagelsesmetaforik. Målet blev at rense sindet og kroppen for det ondes tilstedeværelse. Denne renselsesproces sigtede dobbelt mod det syndige umådeholdne og sanselige liv og mod dettes tegn i kroppens syge og svækkede lemmer og led. Hvis selve beslutningen om at føre et måde- 
holdent, asketisk liv gik hånd i hånd med konkrete tiltag i retning af legemstugt, var man slået ind på renhedens vej.

\section{Renselsen}

Kaptajn Jespersens krav om kamp mod alt »det formløse, uskønne og urene, altså alt det gale $\ll^{81}$ ) var rodfæstet i et ideal om både åndelig og fysisk renhed. Det kolde bad var en integreret del af Kaptajn Jespersens hygiejniske systemer, og det virkede både i retning af en sindets askese og en kropslig renselsesproces. Ligesom den urene sjæl var modbydelig, vakte den urene krop afsky. I sine skrifter vendte Kaptajn Jespersen flere gange tilbage til sin patient, forfatteren Anders Tuborgs sentens, som fremkom efter at Tuborg havde tabt $20 \mathrm{~kg}$ : " Usundhed er som rådne planter - de stinker « ${ }^{82}$ ) Den usunde krop var den smudsige krop, og den bar urenhedens kendemærke: Stanken. To af Kaptajn Jespersens egne bevingede ord var: "Den der ikke bader hver dag, ved ikke hvad det vil sige at leve" samt »Renlighed kommer noest efter Gudsfrygt

Kaptajn Jespersen tilsluttede sig sin 1æremester L P. Mullers teori om, at menneskelegemets udsondringer yar giftige væsker, som hvis de ikke dagligt vaskedes væk ville kunne resultere $i$ et »hygiejnisk krak« for den urene person. ${ }^{84}$ ) Den fysiske renselsesproces krævede ikke bare en daglig afvaskning af legemet, men også gymnastik for at forcere legemets stofskifte til en hurtigere og mere dybtgående udskillelse af affaldsstoffer ${ }^{85}$ )

Kaptajn Jespersens forsøg på at skille det rene fra det urene genfindes i hans lysmetaforik. Kampen mellem ondskabens og godhedens magter var en kamp mellem lys og mørke. Kaptajn Jespersen tilsluttede sig helt Morten Korchfilmenes fastholden af tilværelsens lyse og positive sider overfor den mørke pessimisme: I en morgengymnastikudsendelse i radioen sagde Kaptajn Jespersen:

》- Hvorfor skal Morten Korch vare ene om at skildre livets lyse sider? Om Morten Korch ikke bragte vor tid andet, sà er alene det, at han priser og tror pă lysets sejr over morket, på det godes ret og häb om triumfen vardi, vi skal takke ham for. Han ligefrem tvinger selv de mest inkarnerede sortseere og livskvarulanter, både lag og lard, til at hygge, henholdsvis krympe sig $i$ hans ändelige lys-og renselsesbad; og derved sikrer han sig livets laurbcerkrans. Godmorgen, Morten Korch! « ${ }^{86}$ )

Kaptajn Jespersens tro på lyset og renheden havde psykologisk betydning. Fortrcengningen blev ophøjet til et livsprincip, som kunne hjælpe det tvivlsplagede menneske til fasthed og renhed: "Rul dajernteppet nedfor Fortidens Besvorligheder og indsug i fulde Drag Livets Skonheder og Gloder «*I) Denne appel fra én af radioudsendelserne rettede sig som vanlig først og fremmest mod en fortrængning af sygdomstanker, men også mere generelt om udrensning af allehånde sorger, problemer og konflikter. Igen må Kaptajn Jespersens hygiejneopfattelse forstås på baggrund af hans egen barske 
biografi, for havde han ikke netop selv gennem årtier evnet at overleve og holde fanen hojt ved at tvinge sin opmærksomhed bort fra sin voldsomme omtågethed og svimmelhed og sit dårlige ben? Kaptajn Jespersens gå-påmod og utrolige viljestyrke trods modgang kan ikke blot affærdiges som udslag af fortrængning. Hans bydende og indtrængende måde at tale til andre mennesker på, var et resultat af dyrekøbte erfaringer om, hvordan man kunne stride sig til livskraft og position trods alvorlige handicap. Kaptajn Jespersens mental-hygiejne sugede næring fra hans eget personlige eksempel, hvilket forlenede ham med en aura af troværdighed.

\section{Mentalhygiejne}

Når Kaptajn Jespersen i sit virke som gymnastikpædagog konstant slog til lyd for sindets betydning for helbredelsen må det ses på baggrund af hans egen sygehistorie. Troen på helbredelse, der for Kaptajn Jespersen blev religiøst funderet, oplevede han som en afgørende drivkraft i sin egen helbredelsesproces: Den der »kcemper redeligt" og "uden at vakle tage(r) kampen op mod livets fjender vil på den ene eller anden måde blive belonnet" sagde han. For Kaptajn Jespersen var det altså ikke nødvendigvis selve helbredelseskurens indhold, der er udslagsgivende for helbredelsen, men selve den religiøse og psykiske dynamik bag kuren. Gud kigger mere på hensigten end på midlerne, kunne man vel sige. På denne baggrund bliver det lettere at forstå hvordan Kaptajn Jespersen kunne tro så fuldt og fast på sin egentligt relativt begrænsede bevægelsesterapi, som er blevet kritiseret for slet ikke at stå mål med hans sundhedsvisioner. ${ }^{88}$ )

I sin 25 år lange radiokarriere lå Kaptajn Jespersen ofte i strid med radioledelsen og den del af lytterne, som mente at et gymnastikprogram skulle bestå af gymnastiske øvelser og ikke allehånde hy giejniske råd, som $i$ en lind strøm flød ud af højttalerne, mens man måske stod og blev kold. Kaptajn Jespersens holdning var dog her ganske klar: »Jeg giver ikke lytterne, hvad de vil have, men hvad de tranger til ${ }^{89}{ }^{89}$ )

Og det lytterne »trængte til « var først og fremmest råd om, hvordan de $\mathrm{i}$ hverdagen skulle »røgte og tugte « deres legeme, i mindre grad den konkrete $»$ bøj og stræk«, som Kaptajnen kommanderede. Kaptajn Jespersen erklærede sig da heller ikke utilfreds med, at lytterundersøgelser viste, at kun få procent af hans lyttere udførte øvelserne, mens den overvejende del blot hørte på. For Kaptajn Jespersen var målet nået, hvis folk på lang sigt optog hans hygiejniske budskab og legemliggjorde det i deres egen livsførelse. Denne holdning giver mening, når det erindres, at Kaptajn Jespersen var kommet til den overbevisning, at det forst og fremmest er selve den hygiejniske vilje, der tæller, i mindre grad at man blot lydigt og mekanisk udfører en ordre om at bevæge sig. Her ser vi i øvrigt helt bort fra, at radiomorgengymnastikken for mange givetvis var et humoristisk indslag, som passede glimrende til gassen i sengene og lugten af nybagte kryddere og varm kaffe. 
Kaptajn Jespersens overbevisning om den mentale indstillings og viljestyrkens betydning for sundhed og helbredelse, kan ses $i$ lyset af nyere medicinsk forskning: F.eks. må viljen og evnen til at mobilisere energi vendt mod kræft og forestillinger om troens betydning for et lægemiddels betydning - den såkaldte placebo-effekt vel i dag siges at være velansete medicinske teorier. Den »indre kamp« for »sjælsstyrke«, blev af Kaptajn Jespersen forstået meget rigoristisk, som et krav om at præge sit legeme og aflægge al blødagtighed, men selve kernen, at det kan nytte at arbejde mentalt med en sygdom, kan siges at have fået ny næring i moderne medicinsk tænkning. At radiogymnastikken vitterlig har virket som en åndelig vitaminindsprøjtning for mange mennesker vidner de talrige lytterbreve om. ${ }^{90}$ ) Meget tyder på, at Kaptajnen ikke mindst under besættelsen formåede at hjælpe mange lyttere til at holde modet oppe i den mørke tid. ${ }^{91}$ )

Kaptajn Jespersens brug af mere eller mindre direkte citater af Luther og Paulus har givetvis slået på nogle meget stærke strenge hos mennesker, som i deres skoletid og måske i deres barndomshjem har fået biblen godt og grundigt indprentet. Selv om Kaptajn Jespersens samtidige måske ikke i udpræget grad genkendte citaternes bibelske rødder, har de givetvis fornemmet den særlige bibelske patos, rytme og udtryksmåde.

\section{Lagpraedikanten}

På trods af at Kaptajn Jespersen ikke onskede at blive anset for »en selvglad, halvstuderet idiot på det teologiske område « optrådte han især i den sidste del af sit liv flere gange som prædikant i danske kirker. I det gamle kvindefængsel på Christianshavn holdt han f.eks. foredrag i fængslets kirke. Efter at være trådt tilbage fra radioen gennemforte han på det nærmeste en kirketurné. Hans gennembrudsprædiken foregik i Kastrup ved Vordingborg i 1953, et år efter at han havde forladt radioen. Denne kirkelige optræden affødte stor opmærksomhed i pressen under overskrifter som: "Kaptajn Jespersen prædiker ved højmesse«, »Kaptajn Jespersen på prædikestolen«, »Kirken og idrætten kunde give hinanden meget《 og »Kaptajn Jespersen som prædikant $\ll .^{92}$ ) Kaptajn Jespersens budskab var helt $\mathrm{i}$ tråd med det, der i øvrigt fremlægges $i$ denne artikel, og han så sine prædikener som et forsøg på at vække den idrætsbegejstrede, men lidet kirkeinteresserede danske ungdom af dens »åndelige dvale«. Omvendt blev idrætten set som en inspirationskilde for en noget tam og støvet kirke, som funklede med tomme stole. For Kaptajn Jespersen var idrættens tale i pagt med kirkens budskab, fordi idrætten krævede fair play af sine udøvere. Var man »usand « og snød på idrætspladsen, ville man blive udvist fra banen. Derimod kunne man som kristen godt slippe af med at være from om søndagen, men leve ukristeligt og »usandt« de øvrige seks dage. ${ }^{93}$ ) Indbyderen, pastor Arne Hansens ide med sit initiativ var, at "Kirken og Ungdommen treenger til hinanden $\left.«{ }^{94}\right)$ og han karakteriserede Kaptajn Jespersen som »måske uden selv at vide det... en af vor Tids stor- 


\section{3. juli 1953 - Politiken}

\section{En sund sjael...}

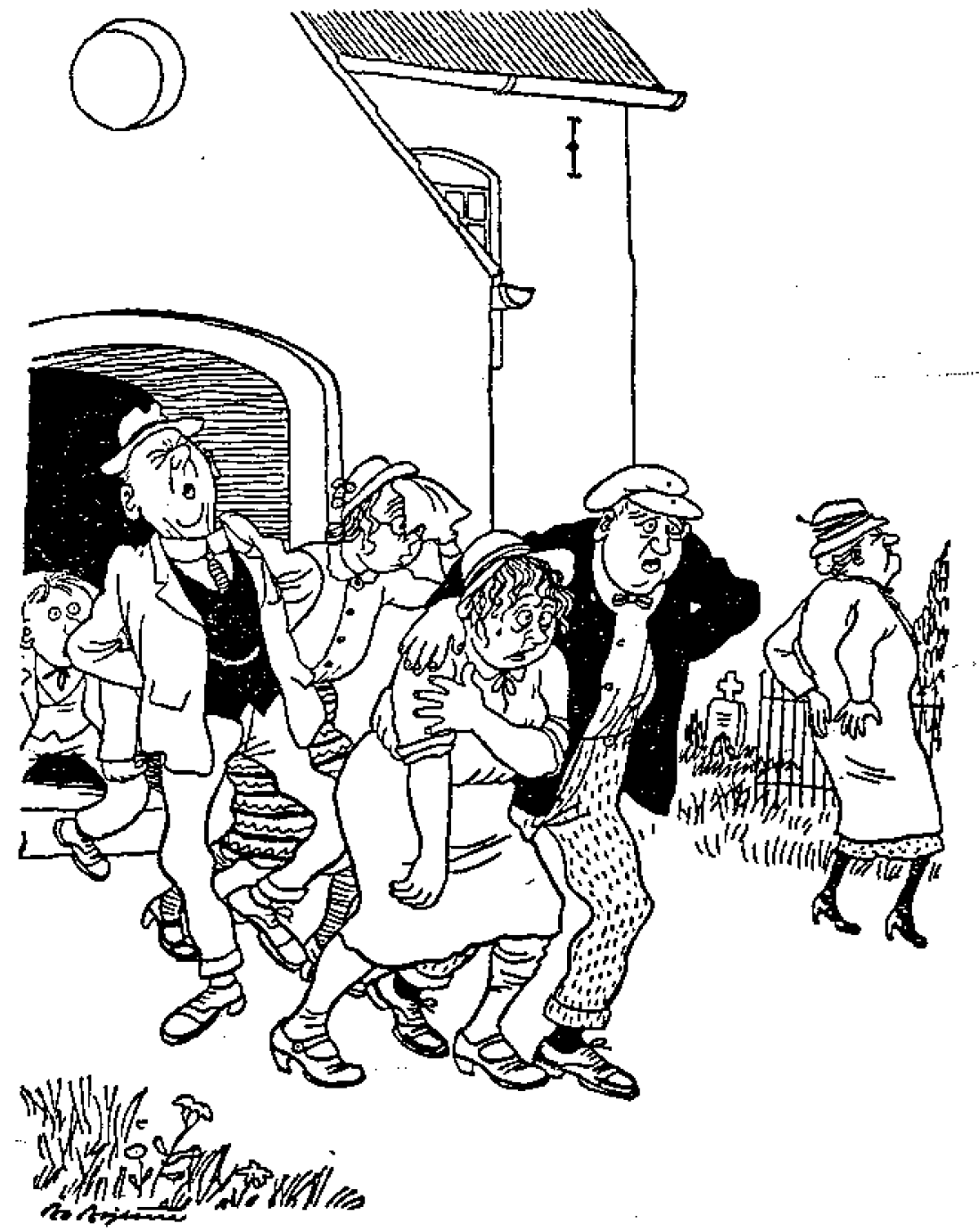

Kaptajn Jespersen skalpaa søndag prodike i Kastmup Kirke ved Vordingborg.

-Duskalse, Maren, neste søndag har de nok sat ribber op foran orglet. 
ste Vakkelsespradikanter , en titel Jespersen ikke uden stolthed tog til sig. Dog fastholdt han gennem alle gæsteprædikerne ikke at tale fra prædikestolen; det var trods alt præstens domæne. ${ }^{95}$ )

Med denne artikel har jeg villet pege på flere overordnede hypoteser:

- Karismatiske gymnastikpædagogers virke er svært at forstå uden en analyse af deres livshistorie.

- Gymnastikkens udvikling bør ikke beskrives isoleret, men som en del af den mere omfattende hygiejnes historie.

- Gymnastikkens og hygiejnens historie lader sig vanskeligt fortælle, uden at deres religiøse dimension tages alvorligt.

- Religion og videnskab, kald og gymnastik er ikke absolutte modsætninger, men levede i et dynamisk samspil inden for mellemkrigstidens hygiejnebevægelse.

- Store gymnastiklederes khårisma og gennemslagskraft bliver mere forståelig i lyset af deres sjæleligt-religiøse livsstemning.

- I takt med at kirkens ritualer mistede mere og mere af deres kraft, trådte nye hy giejniske ritualer f.eks. om legemstugt og psykofysisk renselse i stedet.

-1 hygiejne og gymnastik kunne den defensive religiøse indstilling overvintre endog med den truende naturvidenskab som skjold.

- Gymnastik og hygiejne hjalp mennesker med at gå gennem det tyvende århundredes første halvdel uden total kulturel skizofreni. Dette skete gennem hygiejnens og gymnastikkens legering af århundreders religiøse mentalitet med den moderne (læge)videnskab.

- Den moderne terapikulturs sammensvejsning af religion og kropskultur er ikke ny, men viderefører en tradition fra mellemkrigstiden, omend vægten nu tenderer mod at vippe væk fra den vestlige protestantisme over mofl østlig mystik og filosofi.

- Det vanskeligste spørgsmål for idrætshistorien er derfor ikke: Hvorfor er der sket en forening af gymnastik og religion? Men: Hvorfor forsvandt denne forbindelse i efterkrigstidens åndeløse kropsdyrkelse, hvor gymnastik og hygiejne blev til motion?

Og lad så den gamle sundhedsapostel få det sidste ord:

"Ja, mange menneskeskcebner har jeg truffet, og mange personligheder har jeg fået lov til at mode. I hvert mode var der en oplevelse, som berigede mit liv og gav mig formyet tro pà mit kald. Og dét var en glade hos så mange at mode forståelse for de tanker, jeg giorde mig til talsmand for og det arbejde, jeg søgte at udfore ifolkesundhedens tjeneste. ${ }^{96}>$

Alle illustrationer, inkl. undertekster er hentet fra Kaptajn Jespersens erindringsvere, Mit livs erfaring fra 1958. Dog er tegningen omhandlende Kaptajn Jespersen som leggrredikant hentetfra Politiken, 1953. 


\section{Noter}

1) Citatet er fra det Kaptajn Jespersen inspirerede blad »Sandhed og Sundhed «. Se Jespersen, J.P., Mit livs erfaring, Kbh., 1958, s. 82.

Med denne artikel vil jeg gerne takke Preben Breds og Projekt Danmarks Idrætsmuseum for adgang til arkivmaterialet om Kaptajn Jespersen. Projektets indsamling af arkivalier er ikke kun vigtig ved etableringen af et idrætsmuseum, men også af helt uvurderlig betydning for forskningen $\mathrm{i}$ idrættens historie.

2) Ibid., s. 54.

3) Ibid., s. 9f. Kaptajn Jespersens erindringer fra 1958 skal selvfølgelig tages med et gran salt. Der kan ligge noget tillokkende $i$ at fremstille sin livsgerning $i$ et guddommeligt lys. Ikke desto mindre tyder Kaptajn Jespersens religiøse metaforik også $i$ hans yngre år på, at han ikke blot har tilbageprojiceret sin alderdoms religiøsitet på hele sit hidtidige virke.

4) Ibid., s. 11 .

5) Ibid., s. 12.

6) Ibid., s. 151 .

7) Ibid., s. 15 .

8) Citat fra radioudsendelse b1.a. om Kaptajn Jespersen, DR, PI, 28/1,1988.

9) Jespersen, 1958, s. 16.

10) Med hensyn til socialdarwinismen generelt inden for århundredeskiftets sportsbevægelse, se Bonde H., En stålsat karakter i et hærdet legeme i speciale, Historisk Institut, Københavns Universitet), 1986, s. 22ff.

11) Jvf. artikel af Kaptajn Jespersen i panservåbnets blad »Kentaur«, se Jespersen 1958, s. 6 f.

12) Jespersen, 1958, s. lOf.

13) Ibid., s. 11 .

14)Ibid., s. 9

15) Ibid. s. 14.

16) Ibid.

17) Ibid., s. $14 \mathrm{f}$

18) Ibid., s. 17.

19) Ibid., s. 18.

20) Grof, S., og Halifax, J., Den indre rejse, bd. II, København, 1978. Se også Hillerdal, G. og Gustafsson, B., De så og hørte Jesus, Kristus-åbenbaringer i vor tid, Kbh., 1988.

21) Jespersen, 1958 , s. 19. Med hensyn til Kaptajn Jespersen's eventuelle blufærdighed omkring hvad han oplevede $\mathrm{i}$ de dramatiske sekunder ved hans rideuheld, kan det nævnes, at Kaptajn Jespersens læremester LP. Muller blev komplet til grin, da han begyndte at få spiritistiske visioner om bl.a. at have mødt Jesus. Dette var Kaptajn Jespersen helt på det rene med, Jvf. ibid., s.32f.

22) Muller, LP., Mit System, Kbh., 1904, s. 9.

23) For en analyse af sammenhængen mellem religion og gymnastik/hygiejne bos LP. Muller, se Bonde H., LP. Muller, He-man and Health-Apostle $i$ The International Journal of the History of Sport, London, planlagt til at udkomme i dec. 1989. For analyser i øvrigt af sammenhængen mellem religion og idræt se Gentring 1986/1, Tema: Religion og sport, og i mere empirisk retning: The British Journal of Sports History, London, 1984, vol. 1 no. 2. Tema: Sport and Religion. Se ogsă Ove Korsgaards »programmatiske« artikel om religionens betydning for idrætshistorien: Mellem natur og kultur, ldrætshistorisk årbog, 1987, s. 15 - 23.

24) Jespersen, 1958, s. 18.

25) Ibid., s. 19

26) Ibid.

27) Skiftet i statsmagtens repræsentation på lokalniveau fra præsten til lægen er bl.a. blevet analyseret i Frykman, J., Pure and Rational. The Hygienic Vision, Ethnologia Scandinavica, A Journal for NordkJE/thnology, Lund, 1981, s. $36-63$.

28) Jespersen, 1958, s. $47 / \wedge$ 
29) Ibid., s. 68 .

30) Ibid., s. 49.

31) ibid., s. 78 og 84

32) Ibid., s. 112.

33) Jvf. Kaptajn Jespersen, Navneliste, Institutet, 1935 - 39 og 1939 - 49, samt »Regnskab over deltagerbidrag v. Instituttet, $1927 \ll$. Se »Kaptajn Jespersen arkivet« på Danmarks Højskole for Legemsøvelser.

34) Jespersen, 1958, s. 83. Her hævdes det, at henved dobbelt så mange kvinder som mænd har været regelmæssige, daglige tilhørere til Kaptajn Jespersens morgengymnastik i radioen.

35) Ibid., s. 72.

36) Ibid., s. $48 \mathrm{ff}$.

37) Ibid., s. 48.

38) Ibid., s. 49 og 54.

39) Ibid., s. 137.

40) Ibid., s. 40.

41) Ibid., s. 158 og $48 f$

42) Ibid., s. 48 .

43) Ibid., s. 63.

44) Zerlang, M., Bøndernes klassekamp i Danmark, Kbh., 1976, s. 143 ff. For et forsøg på at koble Max Webers analyse af den protestantiske etik med »sportens ånd «, se Bonde H., Den sportslige askese - om den protestantiske etik og sportens ånd, Centring, Slagelse, 1986 (1).

45) Weber, M., Den protestantiske etik og kapitalismens ånd, Kbh., 1972 (orig. tysk 1920).

46) Zerlang, ibid., s. 161.

47) Ibid., s. 157.

48) Ibid., s. 161.

49) Ibid., s. $170 \mathrm{f}$.

50) Ibid., s. 204.

51) Den Lingsk-inspirerede bondegymnastik, som udbredtes på landet for og efter århundredeskiftet kan ses som den grundtvigianske vækkelses kropslige dimension. Gymnastikkens mål var bl.a. at skabe en gudbilledlig krop.

52) Jespersen, 1958, s. 9.

53) Nedergaard, P. Dansk præste- og sognehistorie, bd. III, Fyns Stift, Kbh. 1956, s. 15 og s. 210 f. og Zerlang, 1976, s. 168.

54) Jvf. Muller, J.P., Kønsmoral og livslykke, Kbh. 1908, s. 1lff.

55) Ibid., s. 112.

56) Jespersen, J.P., Ratslaver og bilmaver, Kbh. 1960, s. 35.

57) Jespersen, 1958, s. 108.

58) Ibid., s. 69.

59) Ibid., s. 116. Udtrykket »Guds Tempel« anvendes dog her af en præst, som priser Kaptajn Jespersens indsats. Om den bibelske oprindelse til dette citat se Paulus, 1 Kor. 3.16,17 og $6.19,20$ og 2 . Kor. 6,16-18.

60) Radioudsendelse, se note 8. Middelalderens hekseforfølgelser synes i øvrigt også i en vis grad at grunde sig på »kropstydning《. At være en gammel skrutrygget, gigtpiaget kone kunne i sig selv være mistænkeliggørende.

61) Jespersen, 1958, s. 121.

62) Ibid., s. 62.

63) Jvf. f .eks. Kurz, R. og Prestera, H., The Body Reveals, New York, 1976, og Politikens massagebog, Kbh., 1986. Vedrørende de bibelske rødder til forestillingen om den gudbilledlige krop, se 1 Mos. 1.26,27, Bibelen, Kbh. 1976.

64) Zerlang, 1976, s. 162.

65) Jvf. f.eks. Kaptajn Jespersen i »Socialdemokraten«, 14/111933.

66) Radioudsendelse, se note 8 . Med »sammenslutningen « menes der givetvis »Landsforeningen »Sandhed og Sundhed «. Kaptajn Jespersens journalskema findes f.eks. i hans bøger 
》Stavsystemet «, Kbh. 1939, s. 47ff. og Legemskultur. Kbh. 1935, s. $12 \mathrm{f}$.

67) Jespersen, 1958, s. 88.

68) Ibid., s. $86 f$.

69) Ibid., s. 142

70) Ibid., s. 9 og 20.

71) Zerlang, 1976, s. 163.

72) Jespersen, J. P., Radio-Morgengymnastik, Kbh., 1928, s. 45. Paulus-citater om at »døde« og »korsfæste k kødet findes i Rom 6.6-13 og 8-13 og Kor 6.13-20 og 9,27 og Gal 5.13-24.

73) Jespersen, 1958, s. 104.

74) Ibid., s. 115.

75) Ibid., s. 38.

76) Jvf. f.eks. Nationaltidende 29 aug. 1953.

77) Analyser af »den autoritære karakterstruktur« og sadomasochismen findes i Zerlang, 1976, s. $198 \mathrm{ff}$ og Brok, Anders, Weimarrepubllkkens sportskritik, i Bidrag, bevidsthedssociologisk tidsskrift, Odense, s. $96-136$ (s. 125ff)

78) Jespersen, 1958 , s. 103. En mere fuldstændig afdækning af de socialpsykologiske forudsætninger for Kaptajn Jespersens kaldsetik ville kræve en analyse af hans og hans patienters og lytteres dybereliggende motivation for at dyrke gymnastik og hygiejne som en form for selvtugt - og i hvilket omfang de overhovedet gjorde det. En foreløbig hypotese kunne være, at Kaptajn Jespersens patienter og deltagerne $\mathrm{i}$ hans Hindsgavl-stævner var at finde blandt de lag, som var på vej opad i samfundet. Det var netop denne gruppe, som tilhørte kernetropperne i den traditionelle puritanisme, jvf. Weber, 1972, s. 108.

79) Jespersen, 1978 , s. 108.

80) Jespersen, 1958, s. 94.

81) Ibid., s. 49

82) Jespersen, 1928 , s. 15 og 1958 s. 156.

83) Jespersen, 1928 , s. 52 og 22.

84) Ibid., s. 23.

85).Ibid., s. 23. Om Jespersens »renselsesfilosofi« se også Hudens Hygiejne og det daglige bad, Kbh., 1926 samt Muller-Øvelser for Skole og Hjem, Kbh., 1921 s. $18 \mathrm{ff}$.

86) Jespersen, 1958, s. 53. Om lysmetaforik, se også s. 90,154 og 157.

87) Jespersen, J.P., Hvis du vil -, Fyn, 1947, s. 46.

88) Dansk Biografisk Leksikon, Kbh., 1981, bd. 7, s. 372.

89) »Kaptajn Jespersens brevsamling«, Projekt Danmarks Idrætsmuseum, DHL.

90) Se »Lytterbreve«, Kaptajn Jespersen-arkivet, DHL.

91) Ibid.

92) Ibid. "Avisudklip 1953, bl.a. Jespersen som lægprædikant og omkring 70-årsdagen. « Avisernes religiøse metaforik fulgte også Kaptajn Jespersen i hans yngre år, jvf. Ibid., "Scrapbook, Kaptajn Jespersen, 1919 - 34«, hvor der f.eks. tales om »sundhedsapostel«, »forkynder«, »mission«, »profet« og »prædiker«, når Kaptajn Jespersens virksomhed făr spalteplads.

93) Ibid., »Avisudklip 1953...«.

94) Næstved Tidende, 8/7,1953.

95) Berlingske Tidende, 19/7,1953.

96) Jespersen, 1958 , s. 146. (min understregning). Afslutningsvis vil jeg gerne takke religionshistorikeren Alex Wittendorff for konstruktiv kritik, herunder ikke mindst påvisningen af Kaptajn Jespersens fundamentalt luthersk - paulinske inspiration.

\section{Litteratur}

Bibelen, den hellige skrifts kanoniske bøger, Kbh., 1976.

Berlingske Tidende, 19/7,1953.

Bonde, H., En stålsat karakter i et hærdet legeme (speciale, Københavns Universitet), 1986. 
Bonde H., Den sportslige akese - om den protestantiske etik og sportens ånd, Centring, Slagelse, $1986(1)$.

Bonde H., LP Muller, He-man and Health-Apostle $\mathrm{i}$ The International Journal of the History of Sport, London, planlagt til at udkomme i dec. 1989.

The British Journal of Sports History, London, 1984, vol. 1 no. 2. Tema: Sport and Religion.

Centring, Slagelse, 1986/1, Tema: Religion og sport.

Dansk biografisk leksikon, Kbh., 1981, bd. 7.

Frykman, J., Pure and Rational. The Hygienic Vision, Ethnologia Scandinavica, A Jornal for Nordic Ethnology, Lund, 1981, s. 36-63.

Hillerdal, G. og Gustafsson, B., De så og hørte Jesus, Kristus-åbenharinger i vor tid, Kbh., 1988.

Gråne L., Evangeliet for folket, Drøm og virkelighed i Martin Luthers liv, Kbh., 1983.

Gregersen, N.H., Teologi og kultur, Århus, 1988.

Gregersen, N.H., Den dobbelte kristendom, i Præsteforeningens blad, Kbh., 1988/40, s. $835-$ 847.

Grof, S., og Halifax, J., Den indre rejse, bd. II, København, 1978.

Jespersen, J.P., »Kaptajn Jespersen-arkivet«, Danmarks Højskole for Legemsøvelser, »Projekt Danmarks Idrætsmuseum «.

Samme, Muller-Øvelser for Skole og Hjem, Kbh., 1921.

Samme, Hudens hygiejne og det daglige bad, Kbh., 1926.

Samme, Radio-Morgengymnastik, Kbh., 1928.

Samme, Legemskultur, Kbh., 1935.

Samme, Stavsystemet, Kbh., 1939.

Samme, Hvis du vil - Fyn, 1947.

Samme, Mit livs erfaring, Kbh., 1958.

Samme, Ratslaver og bilmaver, Kbh., 1960.

Samme, Radioudsendelse, bl.a. om Kaptajn Jespersen, DR, PI, 28/1,1988.

Korsgaard, O., Mellem natur og kultur, I Idrætshistorisk Arbog, Auning, 1987, s. 15-23.

Kurz R., og Prestera, H., The Body Reveals, New York, 1976.

Muller, J.P., Mit System, København, 1904.

Muller, J.P., Kønsmoral og livslykke, Kbh., 1908.

Nationaltidende, 29/8,1953.

Nedergaard, P., Dansk præste og sognehistorie, bd. III, Fyns Stift, Kbh. 1956.

Nastved Tidende, 8/7,1953.

Politikens massagebog, Kbh., 1986.

Socialdemokraten, 14/11,1933.

Wittendorff, A., Rejsen til virkeligheden, Rejsen mod virkeligheden, Den europæiske forestillingsverden fra reformationen til nutiden, Kbh., 1988.

Zerlang, M., Bøndernes klassekamp i Danmark, Kbh., 1976.

\section{Hans Bonde}

Kandidatstipendiat i historie, Kobenhavns Universitet. Licentiatprojekt om gymnastikkens historie i Danmark 1900-1945. 